\title{
The Impact of Introducing the New Corporate Governance Code on the level of Voluntary Risk Disclosure with an Empirical Study on the Egyptian listed Companies
}

\author{
Prof. Reda Ibrahim Abdelkader Saleh \\ Professor of Accounting - Dean of Faculty of commerce, \\ Kafrelsheik University.
}

\section{Dr. Ayman Mohamed Sabry Nokhal Lecturer of Accounting- Faculty of commerce, Kafrelsheik University.}

Sara Mostafa Mohamed Eltantawy Demonstrator in Accounting DepartmentFaculty of commerce, Kafrelsheik University. 
The Impact of Introducing the New Corporate Governance Code on the level of Voluntary Risk Disclosure with an Empirical Study on the Egyptian listed Companies

\begin{abstract}
:
This study aimed to examine the changes in the level of corporate risk disclosures before and after introducing new corporate governance code 2016 and empirically explore the key factors that may affect the extent of voluntary risk information disclosed. The sample of the study consists of 55 companies for years 2014, 2015, 2016 and 2017 . The study used content analysis to identify voluntary risk disclosure. The statistical techniques used to test the hypotheses are parametric techniques that are multiple regression and paired sample t-test.

The findings revealed that the level of voluntary risk disclosure has been improved after issuing new corporate governance rules. The study also found there is a positive significant relationship between role duality, audit committee effectiveness, auditor type and voluntary risk disclosure. On the other hand, there is no significant relationship between board size, board composition, board activity and voluntary risk disclosure.
\end{abstract}

Keywords : Risk Disclosure, New Corporate Governance Code, corporate governance mechanisms.

\title{
1. The General Framework
}

مجلة الاراسات التجارية المعاصرة




\subsection{Introduction}

Today's business environment has been highly competitive and often volatile in nature and very risky due to frequent changes and rapid advancement in technology, society and world politics (Kakanda et al., 2017, p.836 ). At the same time, the business scandals of the late 20th and early 21st century (e.g., Maxwell, Equitable Life, Enron, WorldCom, AIG, Lehman Brothers, Madoff) have shaken the confidence of investors, regulators in the information disclosed in annual report and raise interest in risk disclosure (Saggar \& Singh , 2017, p.378).

Linsley and Shrives (2006, p.389) showed that disclosures have been judged to be risk disclosures, when the users of information received any opportunity or prospect, or any hazard, danger, threat or exposure that this information already impacted on the firm or will impact on the firm in the future.

Examples of those risks include financial risks and nonfinancial risk. Financial risk such as credit risk, liquidity risks, and market risk (IASB, 2008, pp.15-16). Non-financial risks such as operational risk, Empowerment risk, Information processing and technology risk, integrity risk and strategic risk (Linsley and Shrives, 2006, pp.401-402).

Corporate risk disclosure is covered under two main categories, which includes both mandatory and voluntary risk disclosure. Mandatory risk disclosure refers to the risk reporting process that remains mandated by existing rules and formats developed by regulators considered to be instrumental for enhancing the level of transparency of financial reporting (Alzead \& Hussainey, 2017 , p.5). While voluntary risk disclosure is not explicitly required by accounting rules and standards (Hassan , 2013, p.3 ).

According to Deumes (2008, p. 122) "Studying risk disclosure is important because corporate transparency about risk is vital for the well-functioning of capital markets by providing investors with information about the risk associated with pursuing the company's strategic goals, managers can increase transparency and eliminate disparities between what investors understand and expect and what management can deliver". Therefore, risk disclosure conveys the present and potential risks facing firms during the course of business and lead to investor protection, the usefulness of financial reporting, and better risk management (ICAEW, 1997, p.8; Ibrahim., et al, 2018, p.3 ) .

Ineffective risk disclosure may motivate manager to manipulate by internal information about risk and expected benefits 
from companies' activities and use this information to support their own interests that may be against the interests of investors; which leads to increase of information asymmetry, failure of interested parties to take relevant economic decisions and increase agency costs because inability of shareholders to monitor Opportunistic decisions and behaviors for managers in the absence of sufficient risk information (Alzead \& Hussainey, 2017, p.4). Consequently, risk disclosure could be one of the most important disclosure types.

As a result, the importance of risk disclosure for both investors and companies, the bodies are trying to make guidance for this disclosure. The code of corporate governance was updated in August 2016 and paid more attention to risk and risk management disclosure which give us some examples for non-financial risk such as strategic risk, operational risk, reputational risk, and information technology risk. Moreover, this guide support the role of board of directors in identifying the actual and potential risks, threats and uncertainties, assess the level of risk the company is exposed to and develop risk management policies and call for the first time about existence of risk committee management and definite its role .

So, this study aims to examine changes in corporate risk disclosure practices before and after introducing new corporate governance rules 2016 and identify the factors that influence the level of voluntary risk disclosure in the financial reports of Egyptian listed companies.

\subsection{Research Problem}

The business environment in Egypt became very risky and exposed companies to various types of risk. According to EGX annual report, 2016, Egypt has witnessed tough economic conditions in the last period as the country has passed through a series of consecutive political and economic events which had a great impact on Egypt's economic performance, which suffered remarkably from the retreat in the sources of growth, resulting from the weakness of the tourism sector and foreign investments, there was a great pressure on the local currency, which led to the emergence of a black market. This was reflected significantly on the investment climate, especially with the wide gap between the official exchange rate and the black market rate, also the floatation of the Egyptian Pound, implementation the valueadded tax and increased fuel prices (EGX annual report, 2016, p.7).

The surrounding circumstances were not helping to achieve high growth rates, improve the investment climate or restore the investors' confidence. Political uncertainty and instability is expected 
to have negatively affected companies' performance and be reflected in their corporate risk disclosure practices .

Furthermore, studies in Egypt (e.g. Mokhtar \&Mellett 2013; Hassan 2013; Ezat 2014) have found that despite the importance of risk disclosure, most Egyptian companies do not provide investors with relevant information to gain a comprehensive understanding of a company's risk profile and the role of management in managing risks. Risk information has received little importance in Egyptian companies' disclosure practices. So, it become necessary to develop the content of financial reports to include information that improve transparency, increase confidence of users and enable them to expect future performance of company under risk business environment.

So a key question is raised: do the companies disclose about risks they face as a result of these events or none? What drive companies to disclose? Therefore the researcher will try to identify the factors that influence companies to make risk decision or not .

Based on above discussion, we can summarize the research problem in the following two main research questions:-

First question: What is the influence of introducing new corporate governance code on the level of voluntary risk disclosure in the annual reports of Egyptian listed Companies?

Second question: What are the factors that influence the level of voluntary risk disclosure in the annual reports of Egyptian listed Companies?

And to answer the second question we should answer the following sub questions:

1- What is the relationship between board characteristics and the level of voluntary risk disclosure in the Annual Reports of Egyptian listed Companies?

2- What is the relationship between audit committee effectiveness and the level of voluntary risk disclosure in the Annual Reports of Egyptian listed Companies?

3- What is the relationship between auditor type and the level of voluntary risk disclosure in the Annual Reports of Egyptian listed Companies?

\subsection{Research Objectives}

The main objectives of this research are :

1- Examining the influence of introducing new corporate governance code on the level of voluntary risk disclosure in the annual reports of Egyptian listed Companies. 
2- Investigating the factors that influence the level of voluntary risk disclosure in the annual reports of Egyptian listed Companies. objectives:

We can achieve this objective by achieving the following

A- Investigate the relationship between board characteristics and the level of voluntary risk disclosure in the Annual Reports of Egyptian listed Companies .

B- Investigate the relationship between audit committee effectiveness and the level of voluntary risk disclosure in the Annual Reports of Egyptian listed Companies.

C- Investigate the relationship between auditor type and the level of voluntary risk disclosure in the Annual Reports of Egyptian listed Companies

\subsection{Research Importance}

The research may be significant in several aspects and contributes to the literature both in terms of theory and practice.

\section{(A) Theoretical Importance}

1. It is extended to the literature by knowing factors affecting the level of voluntary risk disclosure in Egypt.

2. Risk disclosure could be one of the most value-relevant disclosures and can be considered a new area of research in financial accounting.

(B) Practical Importance

1. Expect to create awareness among companies on the types and level of risk information and how to manage it that they could disclose in their corporate annual reports and can improve corporate transparency.

2. Expect to help the users make appropriate judgments about a company's performance and why companies have risk disclosure and other not and does the company comply with guidance?

3. Research into the factors that influence risk disclosure decisions can provide a way forward to help better explain and understand how to enhance the corporate practice of risk reporting.

\subsection{Research Hypotheses}

In the context of the research problem and its objectives, the following hypotheses can be formulated:

1. There is a difference between the level of voluntary corporate risk disclosures in the annual reports of Egyptian listed companies in years 2014, 2015, and 2016, 2017.

2. There is a significant relationship between board characteristics and the level of voluntary risk disclosure in the Annual Reports of Egyptian listed Companies. 
3. There is a significant relationship between audit committee effectiveness and the level of voluntary risk disclosure in the Annual Reports of Egyptian listed Companies.

4. There is a significant relationship between auditor type and the level of voluntary risk disclosure in the Annual Reports of Egyptian listed Companies.

\subsection{Research Methodology}

In order to achieve the research objectives, the researchers will use the deductive and inductive approaches .

\section{Deductive Approach:}

Theoretical study depends on the deductive approach which will be used to analyze the content of previous studies relevant to the research in order to build a theoretical framework about risk disclosure and factors that drive companies have risk disclosure decision or not.

\section{Inductive Approach:}

Practical side depends on the inductive approach through conducting a content analysis to the sample so as to identify the level of voluntary risk disclosure; types of risk disclosed and combined it to construct an index. Moreover, applying appropriate statistical tools to test research hypotheses.

\subsection{Research Limitations}

The research will be limited to studying factors affecting corporate risk disclosure (a number of corporate governance mechanisms namely Board Size , Board Composition, Board Activity , Role Duality , Audit committee effectiveness , Auditor type) Only and the effect of introducing new corporate governance code on the level of voluntary risk disclosure in the annual reports of Egyptian listed Companies.

The sample of the research will be taken from the Egyptian environment, and it will consist of Companies that are listed in the Egyptian stock exchange except insurance companies and banks.

\subsection{Organization of Research}

In order to achieve the research objectives, the research will be divided into the following sections:

1. The General Framework.

2. Literature review.

3. Basic concept of risk and risk disclosure.

4. Corporate Governance Rules 2016.

5. Hypotheses Development.

6. The Empirical study .

7. Conclusion and recommendations.

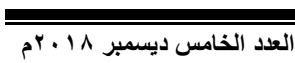




\section{Literature Review}

This section displays the literatures concerned with the relationship between voluntary risk disclosure and corporate governance mechanisms.

\subsection{Ntim et al, (2013)}

The study investigated the nature of risk information disclosed by non-financial companies listed on the Johannesburg Stock Exchange (JSE). The study also examined the influence of corporate governance mechanisms on the quantity and quality of corporate risk disclosure. The sample is based on 169 non-financial companies listed on the Johannesburg Stock Exchange with full data from 2002 to 2011. The results found that companies disclose more information on non-financial risks (i.e., mainly 'operational' and 'strategic' risks)', 'historical', 'good news' and 'qualitative' in nature over the ten-year period investigated. The study also found board diversity, board size and independent non-executive directors were positively related to the extent of corporate risk disclosure. By contrast, dual board leadership structure has no significant connection with the extent of corporate risk disclosure.

\subsection{Al-Shammari, ( 2014 )}

This study investigated the association between corporate governance mechanisms and corporate risk disclosure (CRD) in the annual reports for a sample of 109 Kuwaiti listed non-financial companies in 2012. The results showed that the quantity of risk disclosures in the Kuwaiti companies' annual reports was very limited. The larger board size has a positive impact on corporate risk disclosure. The existences of role duality lead to lower risk disclosure. However, the findings also showed that the association between corporate risk disclosure and other corporate governance characteristics (non-executive directors and the existence of audit committee) were insignificant.

\subsection{Ezat, (2014)}

This study investigated the determinants of disclosing riskrelated information in the annual reports for the EGX100 of Egyptian listed companies for the period between 2009 to 2013. The findings revealed that, comparing with the developed countries, the level of risk disclosure in the Egyptian environment is low. Most of the listed companies disclose information related to strategic risks followed by financial risks and operation risks. Also Egyptian listed companies disclose qualitative, good, past risk-related information. The results found a significant relationship between the risk disclosure and board size, non-executive directors, role duality, firm size, competitive 
pressures, and company's diversification variables. All the variables are positively related to risk disclosure. However, nonexecutive director's variable is related negatively.

\subsection{Allini et al., ( 2016)}

This study examined the relationship between board characteristics and risk disclosure levels in the annual reports of 17 Italian listed companies for the financial years 2008-2011. Independent variables are board size, board meetings, board diversity (gender, age, nationality, professional experience and education), board independence, and audit committee meetings during the year. The main findings suggested that of all the variables, only board diversity significantly affects risk disclosure. Board size, board meetings, board independence and audit committee meetings have no impact on risk disclosure.

\subsection{Carmona, (2016)}

This study explored the necessary and sufficient conditions of good corporate governance practices for high risk disclosure by firms in their annual reports with a sample of 271 Spanish listed companies of financial and non-financial data for years 2006, 2009 and 2012. The study reported that board of director's independence, size, level of activity and gender diversity, CEO duality, audit committee independence, being audited by the Big Four auditing firms and the presence of institutional investors were associated with high risk disclosure.

\subsection{Habbash et al., ( 2016 )}

This study aimed to investigate the extent and the potential influence of corporate governance, ownership structure and corporate characteristics on risk disclosure level, in a developing country that lacks research in this area, Saudi Arabia. The study examined 197 annual reports of Saudi non-financial-listed firms during 2012-2013. The results showed that risk disclosure level in Saudi Arabia was very moderate. Dual role, state ownership, firms' complexity, size and age were positive determinants of risk disclosure. Firm leverage was the only negative determinant. No significant correlations for board independence, institutional ownership, audit committee effectiveness, auditor type, and firm profitability.

\subsection{Kurniawanto et al., (2017)}

The purpose of this study was to examine the effect of corporate governance on corporate risk disclosure. The sample consisted of 200 annual reports from non-financial companies listed in Indonesia Stock Exchange in the period of 2011-2015. The results of this study proved that board size has no effect on corporate risk 
disclosure. The proportion of independent members affected positively on risk disclosures. The control variable, firm size, affected positively on corporate risk disclosures.

\subsection{Saggar \& Singh, (2017)}

This study aimed to measure the extent of voluntary risk disclosure and examine the relationship between corporate governance, firm characteristics impact on risk disclosure in the annual reports of Indian listed companies. The sample consisted of 100 listed Indian non-financial companies. The findings revealed that board size, gender diversity, corporate size and the level of firm risk had a positively significant effect on risk disclosure, whereas CEO duality was negative but had an insignificant effect on risk disclosure and Firm's profitability was negatively significant. On the other hand, the study did not find any significant relationship between board independence, body activity, that is, number of board meetings and risk disclosure.

\subsection{Ibrahim et al., (2018)}

This study investigated the potential influence of corporate governance (Board Independence, Role Duality, Audit Committee Effectiveness, and Auditor Type), ownership structure and corporate characteristics (firm complexity, leverage, size, age, and profitability) on risk disclosure level, in a developing country, Saudi Arabia. This study examined 408 annual reports of Saudi non-financial-listed firms during 2012-2015.The results revealed that the risk disclosure level in Saudi Arabia ranges from zero to a maximum of 36, with an average of 13 sentences. The results provided evidence that none- dual role, audit committee effectiveness, state ownership, firm complexity, size and profitability positively affect risk disclosure. However, the study found no significant correlations for board independence, institutional ownership, auditor type, leverage, and firm age.

\section{Comments on Previous Studies:}

The results of these studies revealed that:

- The level of voluntary risk information disclosed in the annual reports is still minimal and companies are not providing a complete picture of the risks they face.

- The empirical studies show different results on the factors affecting corporate risk disclosure.

- The literature shows there is large variation in risk disclosure practice by companies in terms of categories (i.e. financial and non-financial), nature (i.e. qualitative and quantitative), time frame (i.e. future and past) and type of news (e.g. good and bad). 
The difference between these studies and the current study

1- As mentioned above the studies examined the influence of corporate governance but almost studies were applied to foreign environments and few studies focused on the Egyptian environment.

2- The current study will investigate changes in corporate risk disclosures practices over years 2014, 2015, and 2016, 2017 especially after issuing code of corporate governance 2016.

3- The current study also will examine the factors that may influence the voluntary level of risk disclosure in the light of corporate governance code 2016; for example Corporate governance variables ( board size , board composition ,board activity, role duality, audit committee effectiveness and auditor type ).

\section{Basic concept of risk and risk disclosure}

\subsection{Definition of Risk}

Risk can be seen from either an 'uncertainty- or target based' perspective. The uncertainty based perspective defines risk as 'randomness of uncertainty of future outcomes that can be expressed numerically by a distribution of outcomes' (Dobler, 2008, p. 187). The second perspective, the target based view, defines risk as 'the potential deviation from a benchmark or target outcome' (Dobler, 2008, p. 187).

So Risk is the possible variations or fluctuations in an outcome from what is expected to happen. It arises because what actually happens could differ from what is intended or expected to happen. Risk is often associated with the uncertainty. Whenever risk or uncertainty exists, the future cannot be predicted with certainty. Risk and uncertainty are different. Risk is inherent in the situation itself, whereas uncertainty arises out of ignorance and a lack of information. As a result the uncertainty associated with both potential gain and loss (coyle, 2002, p.2).

\subsection{Risk Categories}

Each firm must categorize its own risks to deal with them effectively. This can be considered an essential step because incorrectly identifying or listing risks can make conducting risk measurement and risk disclosure inaccurate. Reviewing the different risk categories create an understanding of the risks a company has to deal with. There are various risk categories that should be disclosed:

According to ICAEW (1997, pp.27-28) and Cabedo and Tirado, (2004, pp.185-186) argue that risks are usually derived from two factors: external factors, which provide external risks or environment risks (change in consumer preference, competition and 
natural disaster), and internal factors, which provide internal risks or process risks. Internal risks are more controllable than external risks; consequently, providing information about external risks may not be useful, owing to these risks being a function of uncontrollable conditions and actions. Therefore, ICAEW concentrates on internal risks, especially financial and non-financial risks. Financial risk can be categorized into price, liquidity and credit risks. Non-financial risk contains the other internal risks (e.g., operational and decision-making risks). Two other terms are used to refer to these two risk types: direct and indirect risks. Direct or financial risks have a direct effect on a firm's assets and liabilities. Indirect or non-financial risks do not have a direct effect on a firm's assets and liabilities.

Moreover, Linsley \& Shrives, (2006, pp.401-402) and Abraham , Marston and Darby, ( 2012, p.82 ) and Kurniawanto, Suhardjanto, Bandi \& Agustiningsih, ( 2017, pp.266-267) identify risk into two groups: financial and non-financial risks.

1- Financial risks related to the financial position of the company and contain: - Interest rate risk, Exchange rate risk, Commodity risk, Liquidity risk, and Credit risk.

2- Non-financial risks include :- Operational risk (Customer satisfaction, Product development , Efficiency and performance Sourcing, Stock obsolescence and shrinkage , Product and service failure, Environmental, Health and safety, Brand name erosion), Empowerment risk (Leadership and management , Outsourcing, Performance incentives, Change readiness, Communications ), Information processing and technology risk (Integrity, Access Availability, Infrastructure), Integrity risk ( Management and employee fraud, Illegal acts, Reputation) Strategic risk (Environmental scan, Industry, Business portfolio, Competitors, Pricing, Valuation, Planning, Life cycle, Performance measurement, Regulatory, Sovereign and political ) .

\subsection{Definition of Risk Disclosure}

There are various definitions of risk disclosure:- Beretta and Bozzolan, (2004, p.269) defined risk disclosure as:- "The communication of information concerning firm's strategies, characteristics, operations, and other external factors that have the potential to affect expected results".

Hassan, (2009, p.669) defines risk disclosure as: "The financial statementse inclusion of information about managerse estimates, judgments, reliance on market-based accounting policies such as impairment, derivative hedging, financial instruments , internal control risks and fair value as well as the disclosure of

مجلة الدراسات التجارية المعاصرة


concentrated operations, non-financial information about corporations $^{\text {ee }}$ plans, recruiting strategy and other operational, economic, political and financial risks".

\section{Corporate Governance Rules}

Corporate disclosure is governed by the legislations and regulations of the country in which the company operates. In Egypt, a number of legislations rules have been enacted to encourage investment and improve the level of corporate disclosure such as corporate governance rules.

McGee (2010) argues that investors are more willing to invest in companies that adopt strict governance practices as this should improve transparency, reduce the cost of capital and elevate share prices. The ministry of investment published a code of corporate governance principles in October 2005 and then revised and reissued in July 2006. In 2011, the guide was updated and in August 2016 it was merged all previous guides under the name of "the Egyptian Directory of Corporate Governance".

In this code corporate governance (CG) is defined as set of rules, systems and procedures that achieves the best protection and balance between interest of the board of directors, managers, shareholders and other stakeholders.

The code states that it isn't mandatory binding for companies to follow these rules and it represents a guidance on international best practice in corporate management that balance the interests of all related parties . In addition, according to the Egyptian code of CG, companies' managements, auditors and counselors are encouraged to adopt and implement governance rules to attain their potential benefits.

Moreover the code clearly states that companies should apply all rules presented in the guidance and justify if it couldn't apply one of them according to the rule comply or explain and discusses if there is a plan for future implementation of unapplied rules and discloses this report on its website and annual reports.

Concerning risk disclosure and management, the Egyptian code of corporate governance states the following:-

According to rule No. 2-4-3 that have been amended in August 2016 ,the board of directors is generally responsible for identifying the actual and potential risks, threats and uncertainties, assess the level of risk the company is exposed to and develop risk management policies considering the company size, its nature of activities and the market in which it operates. The rule also points out that the board of directors should provide sufficient and clear information on the volume of risks and actions taken to manage these risks. 
Rule No. 2-3-4 has also suggested that the board of directors can form a risk management committee that consists of non-executive and independent board of directors and may be the Managing Director or manager of Risk Management of the company to identify, measure and manage risks facing the company such as strategic risk, operational risk, market risk, reputational risk, information technology risk and all types of risks that may affect company's activities. Finally it should prepare a periodic report on the results of its work and submit it to the board of directors.

Rule 2-3-1 the board of directors should form an audit committee of independent non-executive members; with at least three members; at least one of them is specialized in financial and accounting affairs and holds at least four meetings a year. This committee should perform the task of studying and analyzing the internal control system and preparing a detailed report on it including their recommendations. Also the committee should be responsible for studying and evaluating the early warning systems to detect any defects or deviations that might take place and suggest appropriate actions to take.

* Moreover, rule No 2-4-2 defines the role of the internal audit department in evaluating the methods and procedures for risk management. Whereas the rule shows that all risks (actual and potential) facing a company should be taken into account when designing its internal audit system and procedures.

According to rule No 3-2 each company should disclose about non-financial information that are interested by potential and current investors such as the company's objectives, nature of its activities, its strategic, future prospects, types of risks face it and how to manage it. Also the company should disclose external information that may affect company's operations such as resources and energy that used to continue business and how to solve problems related to its.

Also rule No 3-4-2 the board of directors should prepare annual report to be presented to shareholders and contain at least the following : Discussion of financial results and substantive issues, The main achievements of the company during the year, Analysis of the work environment and markets which company operates, company strategic, any change in management structure, any lawsuit against the company, and the level of commitment to apply the rules of corporate governance and corporate social responsibility. 
It is clearly that this guide corporate governance have paid more attention to risk and risk management disclosure other previously guides but they do not, however, provide further explanation of the meaning of risk, how risks can be measured and reported and the types of actions management should take to manage them. But it is soft law, it is expected that companies will not take it into consideration.

\section{Hypotheses Development}

5.1 The influence of corporate governance rules on voluntary risk disclosure level in the annual reports of Egyptian listed Companies.

The main risk disclosure categories are financial and nonfinancial. The theoretical justification on why companies may provide more financial risk disclosure than other types such as non-financial ones is lined to disclosure requirements which focus on financial aspect. Accounting standards (e.g. IFRS) focus on financial risks, therefore, it is expected that more information on financial risks will be disclosed than on non-financial risks. The previous empirical studies found mixed results. Abid \&Shaiq ,( 2015); Lajili and Zeghal (2005); and Souabni (2011) ; found that the highest volume of risk disclosure related to financial risks which are mandatory. In contrast, Konishi and Ali ,(2007) found that companies in Japan were disclosing more non-financial risks which are voluntary than financial risks.

In the context of Egypt, it is expected that listed companies will provide more information on non-financial risks than financial ones because of issuing new version of corporate governance code in August 2016 and political and economic instability. Therefore, the hypothesis states that:

H1: There is a significant difference between the level of voluntary risk disclosures in the annual reports of Egyptian listed companies in years 2014, 2015, and 2016, 2017.

\subsection{Factors affecting the level of voluntary risk disclosure in} the annual reports of Egyptian listed Companies.

There has been a strong link between corporate governance and disclosure, Corporate governance code and their recommendations support company performance, management effectiveness, and shareholder value and promote confidence in corporate reporting and undoubtedly contribute towards increased transparency and disclosures ( Mallin, 2002, p.253 ). In addition, a range of corporate governance literature contributes to the link between corporate 
governance and risk management and risk disclosure e.g Solomon et al., (2000) and Elshandidy and Neri, (2015) found that good corporate governance has increasing emphasis on corporate risk disclosure. Also Linsley and Shrives , (2005, p.292) argued that "good corporate governance requires directors to be accountable to shareholders for the risks the company faces and improved risk disclosure facilitates greater understanding of the company risk profile". Corporate governance variables used in this study are bored characteristics (board size, board composition, board activity and role duality), audit committee effectiveness and auditor type.

\subsubsection{Board Size}

Managing risk is an important consideration for board of directors; Boards of directors play an important role in company's corporate governance (Agyei-Mensah, 2017, p.10 ). Board size as an important characteristic of the board is refer to as the degree of board of directors of a company or the total number of directors serving on a company's board (Kakanda et al., 2016, p.172 ) . According to agency theory, larger boards incorporate a variety of business expertise leading to more effectiveness in boards' monitoring role resulting in better corporate accountability and disclosure (Singh, et al., 2004, pp.494-495). On the other hand a small board suffers from a shortage of sufficient expertise and high agency costs as a result of the CEO dominance over the boards which in turn impair a board's ability to meet corporate governance responsibilities (Bassett et al., 2007, p.310). Prior risk disclosure studies found mix results. Studies by AlShammari (2014); Carmona et al .,2016 ; Lajili (2009); Ntim et al, (2013); and Saggar \& Singh , (2017); found a positive association between board size and the level of corporate risk disclosure. Whilst Allini,et al.,(2016) ; Beasley et al., (2005); Elzahar and Hussainey (2012) and Kurniawant et al.,(2017) found insignificant results.

Based on the aforementioned theoretical and empirical evidence, the following hypothesis is to be tested:

H2: There is a significant relationship between board size and the level of voluntary risk disclosure in the annual reports of Egyptian listed companies.

\subsubsection{Board Composition}

Board composition is the number of non-executive directors on board of a company (Kakanda et al., 2016 p.174). It is the ratio of non-executive directors to total directors (Marn and Romuald, 2012, p.33). Kakanda ., et al 2017 , p. 838 argued that non-executive directors' representation on the board increases board independence, directors' objectivity, and enhances directors' expertise. On the basis

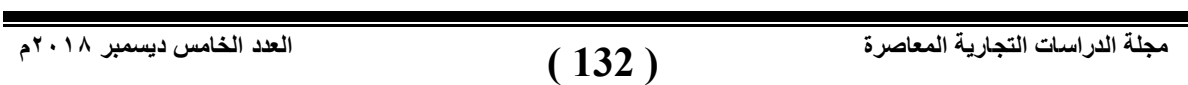


of agency theory, a corporate board that is dominated by a large number of non-executive directors is in a better position to serve in the best interest of the shareholders, and improve firm performance via effective oversight functions on the management. Some prior related studies found a positive relationship between board composition and risk disclosure e.g Lim et al.,( 2007 ); Ntim et al.,( 2013) ; Mensah, (2015) and Oliveira et al,. (2011). Some empirical studies found insignificant results (e.g. Al-shammari, (2014) ; Araham \& Cox, (2007) and Vandemele, (2009), whereas other studies found a negative association (e.g. Barako et al., 2006; Elgammal et al., 2018 ). Accordingly, the hypothesis is formulated as follows:

H3: There is a significant relationship between board composition and the level of voluntary risk disclosure in the annual reports of Egyptian listed companies.

\subsubsection{Board Activity}

Board activity is the number of meetings of the board (Dominguez and Gamez, 2014).Board meeting is viewed as "the gathering of directors on the board to discuss issues regarding the company" (Kakanda et al., 2016). Equally, board meeting serves as a means or an avenue for making effective decisions of a firm. Based on agency theory perspective, with frequency meetings, boards exhibit significant abilities in terms of counselling, penalizing, and overseeing management actions ( Kakanda et al ., 2017) . Hence board meeting is an essential element of corporate governance, and it can have a significant impact on risk information divulgation (Saggar \& Singh, 2017). However empirical studies found mixed results in that some studies found a positive relation between board meetings and volume of information disclosure e.g Banghøj and Plenborg (2008) . Other studies found insignificant relationship e.g Saggar \& Singh (2017); Dominguez \& Gamez 2014; and Allini et al., 2016.

Accordingly, the hypothesis is formulated as follows:

H4: There is a significant relationship between board activity and the level of voluntary risk disclosure in the annual reports of Egyptian listed companies.

\subsubsection{Role Duality}

Role duality or chief executive officer (CEO) refers to a situation in which a single individual serves as both the CEO and chairman of the board. The Chairman is responsible for controlling and managing the board (control function), while CEO is responsible for the day-to-day management (management function) of the firm (Ntim et al., 2013, p.369). This creates a unified leadership structure. According to agency theory, the combined functions can significantly

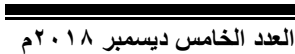


impair the boards' most important function of monitoring, disciplining and compensating senior managers. It also enables the CEO to engage in opportunistic behavior, because of his/her dominance over the board. Such individual who occupied both roles are more likely aligned with management than with shareholders and hence tend to withhold risk information to shareholders (Al-Shammari, 2014, p.56). A dominant personality in both roles poses a threat to monitoring quality and is detrimental to the quality of disclosure. Separating the position of the CEO and chair of board of directors will assist in maintaining board independence, reducing agency costs, improving performance and increasing board effectiveness (Donnelly and Mulcahy, 2008, p.422). Empirical evidence presented mixed conclusions for the relationship between role duality and risk disclosure extent. While Beasley et al., (2005); Carmona et al., (2016); Habbash et al., (2016) and Ibrahim et al., (2018) reported a positive association; Al-Shammari, (2014) ; Elgammal et al., (2018) found a negative association; Vandemele, (2009) ; Elzahar \& Hussaieny, (2012) showed no significant association between role duality and CRD. Accordingly, it is hypothesized that:

H5: There is a significant relationship between role duality and the level of voluntary risk disclosure in the annual reports of Egyptian listed companies.

\subsubsection{Audit Committee Effectiveness}

Audit committee is one of the main pillars of any CG system that derives from the board. This committee can be a monitoring mechanism that improves the quality of information flow between firm owners (shareholders) and managers, especially in the financial reporting environment (Barako et al., 2006, p.112) . Zhang et al., (2013, p.344) explains that the agency theory argument implies that the greater the independence of the audit committee from top management, the more likely it is to advocate the interests of the company's shareholders in terms of reducing information asymmetry. He identified that there are two key roles of audit committees which are firstly to ensure that risks are managed and internal controls exist to guard against risks, and secondly that corporate reports to shareholders are vetted for the integrity of financial and other shareholder-relevant disclosures. He also argues that institution investors put pressure on audit committees in order to provide more information and risk disclosure. However, the effectiveness of this committee depends on its structure and characteristics (Habbash ., et al., 2016, p.6 ). According to rule 2-3-1 of the 2016 Egypt CG code, each firm should establish an audit committee consists of independent 
non-executive members; with at least three members; at least one of them is specialized in financial and accounting affairs and holds at least four meetings a year (CG code, 2016, p.24-25). Like several CG codes, the Egypt code focuses on the number, independence, and expertise of audit committee members .

Empirically, Zhang et al., 2013 found positive relationships between audit committee independence and risk disclosure and insignificant association between risk disclosure financial expertise of audit committee members and risk disclosure. Neri, (2010) ; Oliveira et al. (2011) and Al-Shammari, (2014) found insignificant association between risk disclosure and the presence of an audit committee. Xie et al., (2003) and Soliman and Ragab ,2014) found that audit committees with high number of experts improve the reporting quality. Further, Madawaki \& Amran (2013); Adznan \&Nelson, (2014) and Carmona et al., (2016) found empirical evidence that independent audit committees improve the disclosure quality.Ibrahim et al., (2018) found positive effect between audit committee effectiveness and risk disclosure.

Accordingly, effective audit committees that consist of independent non-executive members, with at least three members, at least one of them is specialized in financial and accounting affairs, and holds at least four meetings a year, will improve the disclosure in general and risk disclosure in particular. Therefore, the hypothesis is:

H6: There is a significant relationship between audit committee effectiveness and the level of voluntary risk disclosure in the annual reports of Egyptian listed companies.

\subsubsection{Auditor Type}

External auditors still play an important role in improving firms overall reporting strategies and they suggest that large audit firms may promote disclosure practice within the company (Alkhatib, 2014, p.860). Elshandidy et al. (2013, p.324) provide evidence that firms having effective audit environments are likely to provide higher level of mandatory and voluntary risk disclosure as compared to other firms. An effective audit environment reduces the conflict between managers and shareholders and reduces the monitoring cost by providing more information (Carcello \& Neal, 2000, p.459). Managers are informative about the risks faced by firms in an effective audit environment because of effective internal reporting on risks and are likely to disclose more (Abid and Shaiq, 2015, p.18). One feature of effective audit environment is Big 4 auditors as they are considered to provide higher audit quality (Abid and Shaiq ,2015 p.18) . Big 4 auditors may legitimate their client firms to provide greater risk 
information in their annual reports to maintain their reputation and avoid reputation costs (Hassan, 2009, p.679). So auditor selection is likely to be related to disclosure decisions hence, clients of Big-4 audit firms are expected to disclose higher levels of information (Uyar 2012, p.246). Empirically, Abid and Shaiq, (2015) ; Alsaeed, (2006) ; Alkhatib, (2014) ; Carmona et al., (2016) ; Fukukawa and kim, (2017) ; and Uyar and Kilic, (2012) found that auditor type positively associated with risk disclosure level. On the other side Deumes \& Knechel, (2008) ; Habbash et al., (2016) ; Oliveira et al., (2011) Ibrahim et al., (2018) found that no significant correlations between auditor type and level of risk disclosure.

In the case of the Egypt, it is expected that higher risk disclosure rates may be positively associated with the Big 4. This is because the Big 4 have wider experience and understanding of the disclosure requirements comparing with other audit firms. Elfeky, (2017) examined the relationship between auditor type and the level of the voluntary disclosure in the Egyptian annual reports and found a positive significant relationship between the external auditor's reputation and the voluntary disclosure. Thus, the following hypothesis has been developed:

H7: There is a significant relationship between auditor type and the level of voluntary risk disclosure in the annual reports of Egyptian listed companies.

\section{The Empirical Study:}

The objectives of the empirical study are to investigate narrative risk disclosure practices within the annual reports, specifically the management report and the notes to financial statements of Egyptian listed companies and test changes in the level of corporate risk disclosures over years 2014, 2015, 2016 and 2017 and to empirically explore the key factors or determinants that may affect the extent and nature of risk information disclosed.

\subsection{Sample Selection and Data Collection}

The sample of this study was selected form Egyptian listed companies according to number of criteria. First, annual reports of the sample companies are available for four years 2014, 2015, 2016, and 2017. Second, all sample companies are separate companies and companies that haven't any branches. Third, only companies that have fiscal years ending on December 31 were considered. Fourth, the study excluded financial and insurance firms because they are regulated by other and different rules which may influence disclosure practice and the nature and type of financial firms and their business activities are different from those of non-financial companies and 
hence they might face other types of risk. So if financial and insurance firms were included, this could confound the results and the analysis would be unrealistic. All annual reports of the sampled companies were obtained from websites of these companies, Naeem brokerage website and Mubasher website.

A number of 55 companies were selected covering wide range of industries which included according to Egyptian stock exchange classification: Basic resources; Chemicals; Construction and Materials; Food and Beverage; Healthcare and Pharmaceuticals; Industrial goods, service and automobile; Oil and gas; Personal and Household products; Real Estate; Retail; Media; Technology; Telecommunication; Travel and Leisure; and Utilities. Table 1 presents the sampled industry sectors with the number of companies and percentage included in each industry sector and appendix 1 shows sample companies included in each industry sector.

Table ( 1 )

Sample companies classified according to industry

\begin{tabular}{|c|c|c|}
\hline Industry Sectors & $\begin{array}{l}\text { Number of } \\
\text { companies }\end{array}$ & Percentage \\
\hline Real Estate & 12 & $21 \%$ \\
\hline Chemicals & 2 & $3.5 \%$ \\
\hline Construction and Materials & 10 & $17.5 \%$ \\
\hline Food and Beverage & 5 & $8.8 \%$ \\
\hline Healthcare and Pharmaceuticals & 2 & $3.5 \%$ \\
\hline $\begin{array}{l}\text { Industrial goods, service and } \\
\text { automobile }\end{array}$ & 7 & $12.7 \%$ \\
\hline Oil and gas & 1 & $1.8 \%$ \\
\hline Personal and Household products & 2 & $3.5 \%$ \\
\hline Basic resources & 2 & $3.5 \%$ \\
\hline Retail & 1 & $1.8 \%$ \\
\hline Media & 1 & $1.8 \%$ \\
\hline Technology & 1 & $1.8 \%$ \\
\hline Telecommunication & 2 & $3.5 \%$ \\
\hline Travel and Leisure & 6 & $10.5 \%$ \\
\hline Utilities & 1 & $1.8 \%$ \\
\hline Total & 55 & $100 \%$ \\
\hline
\end{tabular}




\subsection{Research Method}

The content analysis has been widely used as a method to measure the level and identify the attributes of voluntary risk reporting (Abraham and Cox, 2007; Beretta and Bozzolan, 2004; Lajili and Zéghal, 2005; Linsley and Shrives, (2005; 2006); Linsley, Shrives and Crumpton, 2006; Mousa and Elamir, 2013; Deumes, 2008; Ibrahim., et al 2018). On the same vein, content analysis is used to identify voluntary risk reporting. Following the study of Linsley and Shrives (2006), the content analysis was conducted considering a number of rules which are presented in Appendix 2.

\subsubsection{Measurement of Variables}

\subsubsection{Dependent Variables}

One of the major objectives of this study is to investigate the level of voluntary risk disclosure by the Egyptian listed companies. For voluntary risk disclosure, it will be measured by the count of risk related sentences through a content analysis of annual reports of sampled companies.

\subsubsection{Independent Variables}

Another major objective of this study is to identify the factors affecting corporate risk disclosure by examining the relationship between the level of voluntary risk disclosure and a number of corporate governance mechanisms namely Board Size, Board Composition, Board Activity, Role Duality, Audit committee effectiveness, and auditor type .Therefore, to test the hypotheses, each of these independent variables will be measured.

1. Board Size: it is measured by the number of board members.

2. Board Composition: it is measured by the number of nonexecutive directors to total number of directors on the board of a firm.

3. Board Activity: it is measured by the number of meetings of the board.

4. Role Duality: is a dummy variable whereby 1 is given if CEO is the chairman and 0 if otherwise.

5. Audit Committee Effectiveness: is a weighted average based on four conditions; firstly the audit committee consists of fully independent members, secondly the audit committee consists of three members at least, thirdly the audit committee consists of one a financial expert and fourthly the audit committee holds at least four meetings a year. If one condition is exist, it takes the value $1 / 4$; if two condition is exist, it takes the value $2 / 4$; if three condition is exist it, takes the value $3 / 4$; if four condition is exist, it takes the value $4 / 4$ and zero otherwise. 
6. Auditor Type: is a dummy variable that takes the value one if the firm is audited by one of the big-4 auditors, and zero otherwise. The Big 4 auditors are Office of KPMG " Hazem Hassan " , Ernst and young office "E\&Y " "Allied for accounting and auditing " "Emad Hafez Ragheb" , Price Water House Office "Farid Mansour" and Deloitte Cairo Office " Saleh and Brosom and Abdul Aziz".

\subsection{Statistical Techniques}

In order to determine statistical techniques that will be used, a normality test was performed to statistically assess whether data comes from a normal distribution or not. According to KolmogorovSmirnov test, the null hypothesis for this is that the data is normally distributed. The Sig for the dependent variables were more than 0.05, which means that the null hypothesis is accepted. So the statistical techniques selected for testing the research hypotheses are parametric techniques. Parametric techniques that will be conducted are multiple regressions, and paired sample t-test. The following table (2) shows the results of Kolmogorov-Smirnov test.

Table ( 2 )

One-Sample Kolmogorov-Smirnov Test

\begin{tabular}{|l|c|c|}
\hline & $\begin{array}{c}\text { Kolmogorov- } \\
\text { Smirnov Z }\end{array}$ & $\begin{array}{c}\text { Asymp. Sig. (2- } \\
\text { tailed) }\end{array}$ \\
\hline Voluntary Risk Disclosure 2017 & 1.119 & .163 \\
\hline $\begin{array}{l}\text { Average Voluntary Risk Disclosure } \\
\text { 2014- 2015 }\end{array}$ & 1.254 & .086 \\
\hline $\begin{array}{l}\text { Average Voluntary Risk Disclosure } \\
\text { 2016-2017 }\end{array}$ & 1.356 & .051 \\
\hline
\end{tabular}

\subsubsection{Testing the Validity of Regression Analysis}

Before conducting multiple regression analysis, it is useful to check the existence of multicollinearity between the independent variables. Multicollinearity means that two or more of the independent variables are highly correlated and this situation can damage effects on results of multiple regressions. There is multicollinearity if coefficient correlation between the independent variables is more than 0.7 and the relationship between them are significant.

The correlation matrix is a powerful tool for getting a rough idea of the relationship between predictors.

The results showed that the correlation between each of independent variables wasn't too high; the highest values of correlation coefficients were found between board composition, board activity and between role duality, audit committee 
effectiveness with values of (.300),(.296) respectively. These correlations between the variables were acceptable. So there is no multicollinearity between the independent variables and consequently there is no influencing on the results. Table 6-3 shows Correlations between independent variables.

Table ( 3 )

\section{Correlations between independent variables}

\begin{tabular}{|c|c|c|c|c|c|c|c|}
\hline & & $\mathrm{X} 1$ & $\mathrm{X2}$ & $\mathrm{X3}$ & $\mathrm{X4}$ & $\mathrm{X5}$ & $\mathrm{X6}$ \\
\hline \multirow[t]{3}{*}{$\mathrm{X} 1$} & $\begin{array}{l}\text { Pearson } \\
\text { Correlation }\end{array}$ & 1 & .198 & .250 & .255 & .125 & .212 \\
\hline & Sig. (2-tailed) & & .148 & .066 & .061 & .362 & .120 \\
\hline & $\mathrm{N}$ & 55 & 55 & 55 & 55 & 55 & 55 \\
\hline \multirow[t]{3}{*}{$\mathrm{X} 2$} & $\begin{array}{l}\text { Pearson } \\
\text { Correlation }\end{array}$ & .198 & 1 & $.300^{*}$ & .154 & $-.051-$ & $-.012-$ \\
\hline & Sig. (2-tailed) & .148 & & .026 & .262 & .713 & .930 \\
\hline & $\mathrm{N}$ & 55 & 55 & 55 & 55 & 55 & 55 \\
\hline \multirow[t]{3}{*}{ X3 } & $\begin{array}{l}\text { Pearson } \\
\text { Correlation }\end{array}$ & .250 & $.300^{*}$ & 1 & .135 & .162 & .261 \\
\hline & Sig. (2-tailed) & .066 & .026 & & .324 & .238 & .055 \\
\hline & $\mathrm{N}$ & 55 & 55 & 55 & 55 & 55 & 55 \\
\hline \multirow[t]{3}{*}{$\mathrm{X} 4$} & $\begin{array}{l}\text { Pearson } \\
\text { Correlation }\end{array}$ & .255 & .154 & .135 & 1 & $.296^{*}$ & .072 \\
\hline & Sig. (2-tailed) & .061 & .262 & .324 & & .028 & .603 \\
\hline & $\mathrm{N}$ & 55 & 55 & 55 & 55 & 55 & 55 \\
\hline \multirow[t]{3}{*}{$\mathrm{X} 5$} & $\begin{array}{l}\text { Pearson } \\
\text { Correlation }\end{array}$ & .125 & $-.051-$ & .162 & $.296^{*}$ & 1 & .205 \\
\hline & Sig. (2-tailed) & .362 & .713 & .238 & .028 & & .133 \\
\hline & $\mathrm{N}$ & 55 & 55 & 55 & 55 & 55 & 55 \\
\hline \multirow[t]{3}{*}{ X6 } & $\begin{array}{l}\text { Pearson } \\
\text { Correlation }\end{array}$ & .212 & $-.012-$ & .261 & .072 & .205 & 1 \\
\hline & Sig. (2-tailed) & .120 & .930 & .055 & .603 & .133 & \\
\hline & $\mathrm{N}$ & 55 & 55 & 55 & 55 & 55 & 55 \\
\hline
\end{tabular}

\subsubsection{The Statistical Model}

In order to examine the relationship between the level of voluntary risk disclosure (the dependent variable) and corporate governance characteristic (the independent variables discussed above), the following regression model is employed:

$\mathrm{CRD}=\beta_{0}+\beta_{1} \mathrm{X}_{1}+\beta_{2} \mathrm{X}_{2}+\beta_{3} \mathrm{X}_{3}+\beta_{4} \mathrm{X}_{4}+\beta_{5} \mathrm{X}_{5}+\beta_{6} \mathrm{X}_{6}+\mathrm{U}$ Where: 
$\mathrm{CRD}=$ The level of voluntary risk disclosure

$\beta 0=$ The intercept

$\mathrm{X} 1=$ Board Size

$\mathrm{X} 2$ = Board Composition

$\mathrm{X} 3$ = Board Activity

$\mathrm{X} 4=$ Role Duality

$\mathrm{X} 5=$ Audit committee effectiveness

$\mathrm{X} 6=$ Auditor type

$\mathrm{U}=$ Error term

\subsection{Data Analysis and Results}

The collected data were analyzed by using Statistical Package for Social Science (SPSS) version 21.

\subsubsection{Descriptive Statistics}

Descriptive statistics are used to describe the basic features of the data in the study. It divided into two sections in this study; the first section presents the descriptive statistics of dependent and independent variables, the second section presents the descriptive statistics of the characteristics of voluntary risk disclosure. The following table shows the descriptive statistics of dependent and independent variables.

Table ( 4 )

Descriptive statistics of dependent and independent variables.

\begin{tabular}{|c|c|c|c|c|c|}
\hline & Minimum & Maximum & Mean & $\begin{array}{c}\text { Standard } \\
\text { Deviation }\end{array}$ & $\mathbf{N}$ \\
\hline $\begin{array}{c}\text { Voluntary risk } \\
\text { disclosure 2017 }\end{array}$ & 12.00 & 83.00 & 33.5091 & 18.50012 & 55 \\
\hline X1 Board Size & 3.00 & 16.00 & 8.5636 & 3.21895 & 55 \\
\hline $\begin{array}{c}\text { X2 Board } \\
\text { Composition }\end{array}$ & .00 & .93 & .6690 & .20055 & 55 \\
\hline $\begin{array}{c}\text { X3 Board } \\
\text { Activity }\end{array}$ & 2.00 & 28.00 & 8.3091 & 5.19213 & 55 \\
\hline \begin{tabular}{c} 
X4 Role Duality \\
\hline $\begin{array}{c}\text { X5 Audit } \\
\text { committee } \\
\text { effectiveness }\end{array}$
\end{tabular} & .00 & 1.00 & .4182 & .49781 & 55 \\
\hline X6 Auditor type & .00 & 1.00 & .4364 & .50050 & 55 \\
\hline
\end{tabular}

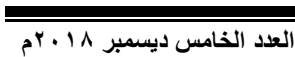


The table shows the following:

1- The mean of voluntary risk disclosure is 33.5091 with standard deviation 18.50012 that means high level of voluntary risk disclosure and this is due to the business environment in Egypt became very risky because the political instability and exceptional economic circumstance. Almost disclosure is about the effect of these events on companies' performance. So the companies disclosed to justify its poor performance to shareholders such as closing some branches and achieving losses.

2- The mean of Board Size is 8.5636 with standard deviation 3.21895 that means No. of member in the board equal 8 and there is very high level of dispersion between sampled companies.

3- The mean of Board Composition is .6690 with standard deviation .20055 that means $66 \%$ of board directors in sampled companies are non-executive directors. Moreover, there is very high level of dispersion between sampled companies.

4- The mean of Board Activity is 8.3091 with standard deviation 5.19213 that means almost number of board meeting in sampled companies equal 8 times in the year and this is good indicator because according to code of corporate governance 2016 number of board meeting equal 4 times in the year.

5- The mean of Role Duality is .4182 with standard deviation .49781 that means $41 \%$ from sampled companies chief executive officer serves as both the CEO and chairman of the board.

6- The mean of Audit committee effectiveness is .6682 with standard deviation .17384 that means $66 \%$ of audit committee in sampled companies is effective. Moreover, there is very high level of dispersion between sampled companies.

7- The mean of Auditor type is .4364 with standard deviation .50050 that means $43 \%$ of sampled companies audited by Big 4 .

The following table shows the descriptive statistics of the characteristics of voluntary risk disclosure. 
Table ( 5 )

Descriptive statistics of voluntary risk information characteristics.

\begin{tabular}{|c|c|c|c|c|c|}
\hline & Minimum & Maximum & Mean & $\begin{array}{l}\text { Standard } \\
\text { deviation }\end{array}$ & $\begin{array}{c}\text { No of } \\
\text { sentencs }\end{array}$ \\
\hline \begin{tabular}{|l} 
Type of \\
information \\
Qualitative \\
\end{tabular} & 3.00 & 44.00 & 18.4364 & 10.43989 & 1014 \\
\hline \begin{tabular}{|l} 
Type of \\
information \\
Quantative \\
\end{tabular} & 1.00 & 47.00 & 15.0727 & 12.24572 & 829 \\
\hline $\begin{array}{l}\text { Time } \\
\text { orientation Past }\end{array}$ & 3.00 & 75.00 & 24.4545 & 14.62851 & 1345 \\
\hline $\begin{array}{l}\text { Time } \\
\text { orientation } \\
\text { future }\end{array}$ & .00 & 45.00 & 10.1633 & 10.54622 & 498 \\
\hline $\begin{array}{l}\text { Type of news } \\
\text { Good }\end{array}$ & 1.00 & 50.00 & 15.6364 & 9.40521 & 860 \\
\hline $\begin{array}{l}\text { Type of news } \\
\text { Bad }\end{array}$ & 1.00 & 58.00 & 18.2037 & 15.69206 & 983 \\
\hline \begin{tabular}{|l} 
Type of news \\
Neutral
\end{tabular} & & & & & 0 \\
\hline \begin{tabular}{|l}
$\begin{array}{l}\text { Financial risk } \\
\text { disclosure }\end{array}$ \\
\end{tabular} & 1.00 & 19.00 & 6.8727 & 4.73777 & 378 \\
\hline $\begin{array}{l}\text { Operational } \\
\text { risk disclosure }\end{array}$ & 1.00 & 34.00 & 9.0000 & 8.25536 & 486 \\
\hline $\begin{array}{l}\text { Empowerment } \\
\text { risk disclosure }\end{array}$ & 1.00 & 8.00 & 2.9600 & 1.61967 & 74 \\
\hline $\begin{array}{l}\text { Information } \\
\text { technology risk } \\
\text { disclosure }\end{array}$ & 1.00 & 16.00 & 3.8571 & 5.42920 & 27 \\
\hline $\begin{array}{l}\text { Integrity risk } \\
\text { disclosure }\end{array}$ & & & & & 0 \\
\hline \begin{tabular}{|l} 
Strategic risk \\
disclosure
\end{tabular} & .00 & 42.00 & 15.9636 & 10.97634 & 878 \\
\hline $\begin{array}{l}\text { Legal risk } \\
\text { disclosure }\end{array}$ & & & & & 0 \\
\hline
\end{tabular}

It is clearly shown in the table that, for the sampled companies, Egyptian listed companies disclose more Qualitative risk information than quantative risk information, past risk information than future risk information, bad risk information than good and neutral risk 
information. Moreover, sampled companies disclose firstly strategic risk information, secondly operational risk information, thirdly financial risk information, fourthly empowerment risk information, fifthly information processing and technology risk information.

\subsubsection{Multiple regressions results analysis and Testing of research hypotheses}

To check the significance of the model and explain the relationship between six independent variables and dependent variable, multiple regression analysis was conducted by using enter method. The following tables presents results of multiple regression analysis.

Table ( 6 )

Model Summary by using enter method

\begin{tabular}{||c|c|c|c|c|}
\hline Model & R & R Square & Adjusted R Square & $\begin{array}{c}\text { Std. Error of } \\
\text { the Estimate }\end{array}$ \\
\hline \hline 1 & .754 & .569 & .515 & 12.88881 \\
\hline
\end{tabular}

The results showed that:

1- The value of $R$ equal .754 which means there is strong correlation between dependent variable and independent variables.

2- The value of R Square equal .569 which means $56.9 \%$ of variation in dependent variable due to the variance in independent variables and $43.1 \%$ was due to other factors.

3- Adjusted R Square used for the same purpose of R Square but its more accurate to judge goodness of the model.

Table ( 7 )

ANOVA

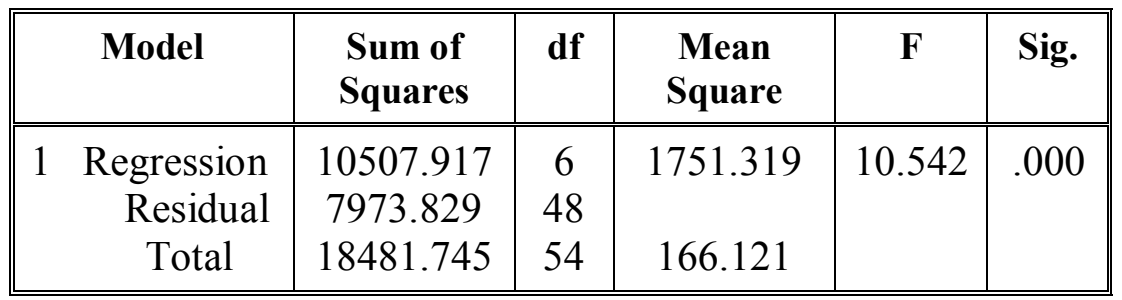

The results showed that Sig equal.000 which means the regression model is significant. 
Table ( 8 )

Multiple regression model by using enter method

\begin{tabular}{|l|c|c|c|c|c|}
\hline \multicolumn{1}{|c|}{ Model } & B & $\begin{array}{c}\text { Std. } \\
\text { Error }\end{array}$ & t & Sig. & Decision \\
\hline \hline X1 Board Size & $-.739-$ & .590 & $-1.253-$ & .216 & Insignificant \\
\hline $\begin{array}{l}\text { X2 Board } \\
\text { Composition }\end{array}$ & 8.600 & 9.444 & .911 & .367 & Insignificant \\
\hline $\begin{array}{l}\text { X3 Board } \\
\text { Activity }\end{array}$ & $-.434-$ & .376 & $-1.155-$ & .254 & Insignificant \\
\hline $\begin{array}{l}\text { X4 Role } \\
\text { Duality }\end{array}$ & 11.306 & 3.827 & 2.954 & .005 & significant \\
\hline $\begin{array}{l}\text { X5 Audit } \\
\text { Committee } \\
\text { effectiveness }\end{array}$ & 49.473 & 10.899 & 4.539 & .000 & significant \\
\hline $\begin{array}{l}\text { X6 Auditor } \\
\text { Type }\end{array}$ & 14.513 & 3.746 & 3.875 & .000 & significant \\
\hline
\end{tabular}

\section{Testing the first hypothesis}

H0: There is no significant difference between the level of voluntary corporate risk disclosures in the annual reports of Egyptian listed companies in years 2014, 2015, 2016, and 2017.

H1: There is a significant difference between the level of voluntary corporate risk disclosures in the annual reports of Egyptian listed companies in years 2014, 2015, and 2016, 2017.

Paired sample t-test was conducted to evaluate whether the average voluntary risk disclosure in 2016 and 2017 is higher than the average voluntary in 2014 and 2015.The following table presents the results of paired sample t-test.

Table ( 10 )

Paired Samples test

\begin{tabular}{|c|c|c|c|c|c|c|c|c|}
\hline & \multicolumn{5}{|c|}{ Paired differences } & \multirow[b]{3}{*}{-} & & \multirow[b]{3}{*}{ 通 } \\
\hline & \multicolumn{5}{|c|}{$95 \%$ confidence interval of the difference } & & \multirow[b]{2}{*}{ 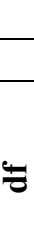 } & \\
\hline & $\sum_{\Sigma}^{\bar{\Xi}}$ & 密 & 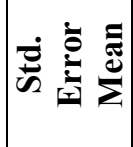 & 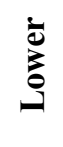 & 苛 & & & \\
\hline \begin{tabular}{|c|} 
Average voluntary \\
risk disclosure \\
$2014-2015$ and \\
Average voluntary \\
risk disclosure \\
$2016-2017$
\end{tabular} & $\begin{array}{l}\text { ¿ } \\
\infty \\
\infty \\
\infty \\
\end{array}$ & 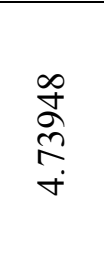 & $\begin{array}{l}\hat{8} \\
\text { రิ }\end{array}$ & $\begin{array}{l}\infty \\
0 \\
0 \\
6 \\
+ \\
+\end{array}$ & 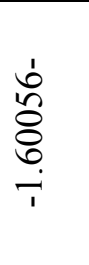 & $\begin{array}{l}8 \\
\text { ஜn } \\
+\end{array}$ & in & $\S$ \\
\hline
\end{tabular}


As shown in the above table, The Significance for average voluntary risk disclosure 2016-2017 and average voluntary risk disclosure 2014-2015 are less than 0.05, which means that the null hypothesis is rejected. So there is a significant difference between the level of voluntary corporate risk disclosures in the annual reports of Egyptian listed companies in years 2014, 2015, and 2016, 2017.

\section{Testing the second hypothesis}

H0: There is no significant relationship between board size and the level of voluntary risk disclosure in the annual reports of Egyptian listed companies.

H1: There is a significant relationship between board size and the level of voluntary risk disclosure in the annual reports of Egyptian listed companies.

Based on the results of third table 6-8 "Multiple regression model by using enter method" the Significance of board size is .216 that is more than 0.05 which means the null hypothesis is accepted. Moreover, the signal of $\mathrm{B}$ is negative so there is insignificant negative relationship between board size and the level of voluntary risk disclosure in the annual reports of Egyptian listed companies in year 2017.

\section{Testing the third hypothesis}

H0: There is no significant relationship between board composition and the level of voluntary risk disclosure in the annual reports of Egyptian listed companies.

H1: There is a significant relationship between board composition and the level of voluntary risk disclosure in the annual reports of Egyptian listed companies.

Based on the results of third table 6-8 "Multiple regression model by using enter method" the Significance of board composition is .367 that is more than 0.05 which means the null hypothesis is accepted. Moreover, the signal of B is positive so there is insignificant positive relationship between board composition and the level of voluntary risk disclosure in the annual reports of Egyptian listed companies in year 2017.

\section{Testing the fourth hypothesis}

H0: There is no significant relationship between board activity and the level of voluntary risk disclosure in the annual reports of Egyptian listed companies.

H1: There is a significant relationship between board activity and the level of voluntary risk disclosure in the annual reports of Egyptian listed companies. 
Based on the results of third table 6-8 "Multiple regression model by using enter method" the Significance of board activity is .254 that is more than 0.05 which means the null hypothesis is accepted. Moreover, the signal of $\mathrm{B}$ is negative so there is insignificant negative relationship between board activity and the level of voluntary risk disclosure in the annual reports of Egyptian listed companies in year 2017.

\section{Testing the fifth hypothesis}

H0: There is a significant relationship between role duality and the level of voluntary risk disclosure in the annual reports of Egyptian listed companies.

H1: There is no significant relationship between role duality and the level of voluntary risk disclosure in the annual reports of Egyptian listed companies.

Based on the results of third table 6-8 "Multiple regression model by using enter method" the Significance of role duality is .005 that is less than 0.05 which means the null hypothesis is rejected. Moreover, the signal of $\mathrm{B}$ is positive so there is significant positive relationship between role duality and the level of voluntary risk disclosure in the annual reports of Egyptian listed companies in year 2017.

\section{Testing the sixth hypothesis}

H0: There is no significant relationship between audit committee effectiveness and the level of voluntary risk disclosure in the annual reports of Egyptian listed companies.

H1: There is a significant relationship between audit committee effectiveness and the level of voluntary risk disclosure in the annual reports of Egyptian listed companies.

Based on the results of third table 6-8 "Multiple regression model by using enter method" the Significance of audit committee effectiveness is .000 that is less than 0.05 which means the null hypothesis is rejected. Moreover, the signal of B is positive so there is significant positive relationship between audit committee effectiveness and the level of voluntary risk disclosure in the annual reports of Egyptian listed companies in year 2017.

\section{Testing the seventh hypothesis}

H0: There is no significant relationship between auditor type and the level of voluntary risk disclosure in the annual reports of Egyptian listed companies.

H1: There is a significant relationship between auditor type and the level of voluntary risk disclosure in the annual reports of Egyptian listed companies.

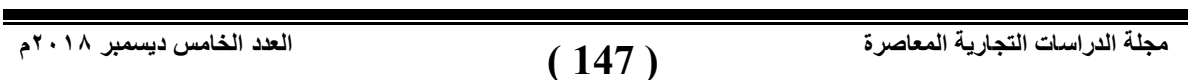


Based on the results of third table 6-8 "Multiple regression model by using enter method" the Significance of auditor type is .000 that is less than 0.05 which means the null hypothesis is rejected. Moreover, the signal of $\mathrm{B}$ is positive so there is significant positive relationship between auditor type and the level of voluntary risk disclosure in the annual reports of Egyptian listed companies in year 2017.

\section{Research Conclusion and Recommendations 7.1 Conclusion}

This study aimed to test changes in the level of corporate risk disclosures over years 2014, 2015, 2016 and 2017 and empirically explore the key factors that may affect the extent and nature of voluntary risk information disclosed. The empirical findings showed that:

1- There is a significant increase between the level of voluntary corporate risk disclosures in the annual reports of Egyptian listed companies in years 2014, 2015, and 2016, 2017. The total number of sentences for voluntary risk disclosure 2014-2015 equal 3233 and total number of sentences for voluntary risk disclosure 2016-2017 equal 3550 which means very low difference and sampled companies don't take corporate governance code 2016 into their consideration. These results matched with the study of Ezat 2014 that investigated the level of risk disclosure during the period from 2009 to 2013 with a sample of 84 listed companies and found the level of risk disclosure in the annual reports is low .

2- There is no significant relationship between board size and the level of voluntary risk disclosure in the annual reports of Egyptian listed companies. This result matched with the study of Allini et al., (2016) ; Beasley et al., (2005); Elzahar and Hussainey (2012) and Kurniawant et al., (2017).

3- There is no significant relationship between board composition and the level of voluntary risk disclosure in the annual reports of Egyptian listed companies. This result matched with the study of Al-shammari, (2014); Araham \& Cox, (2007) and Vandemele, (2009).

4- There is no significant relationship between board activity and the level of voluntary risk disclosure in the annual reports of Egyptian listed companies. This result matched with the study of Saggar \& Singh (2017); Dominguez \& Gamez 2014; and Allini et al., 2016. 
5- There is a significant positive relationship between role duality and the level of voluntary risk disclosure in the annual reports of Egyptian listed companies. This result matched with the study of Beasley et al., (2005); Carmona et al., (2016) ;Habbash et al., (2016 ) and Ibrahim et al., (2018).

6- There is a significant positive relationship between audit committee effectiveness and the level of voluntary risk disclosure in the annual reports of Egyptian listed companies. This result matched with the study of Ibrahim et al., (2018).

7- There is a significant positive relationship between auditor type and the level of voluntary risk disclosure in the annual reports of Egyptian listed companies. This result matched with the study of Abid and Shaiq, (2015) ; Alsaeed, (2006) ; Alkhatib, (2014) ; Carmona et al., (2016) ; Fukukawa and kim, (2017) ; Elfeky, (2017) and Uyar and Kilic (2012).

\subsection{Recommendations}

Based on the empirical conclusions of the research, the researcher can provide the following recommendation -:

1- The listing rules in the Egyptian stock exchange should require companies to prepare a separate statement to report risk information within such as the Management Discussion and Analysis (MD\&A).

2- The regulators should promote and monitor the application of the Egyptian Code of Corporate Governance 2016 to enhance the disclosure and impose penalties against companies that violate the code. 


\section{References}

1. Abid,A. Shaiq,M. (2015) . A Study of Risk Disclosures in the Annual Reports of Pakistani Companies: A Content Analysis. Research Journal of Finance and Accounting.Vol.6, No.11,pp.14-24.

2. Abraham, S . Marston,C . Darby, P. 2012 . Risk reporting - clarity, relevance and location, Edinburgh : institute of chartered accountants of Scotland. available at : https://www.icas.com/technical-resources/publication-riskreporting-clarity-relevance-and-location. Accessed at 16 October 2016.

3. Abraham, S., \& Cox, P. (2007). Analysing the determinants of narrative risk information in UK FTSE 100 annual reports. The British Accounting Review, Vol.39, No.3, pp.227-248.

4. Adznan,S., Nelson,S.P. 2014. Financial instruments disclosure practices: Evidence from Malaysian listed firms. Social and Behavioral Sciences, Vol.164, pp.62 - 67.

5. Agyei-Mensah,B.2017 "The relationship between corporate governance mechanisms and IFRS 7 compliance : Evidence from an emerging market.", Corporate Governance: The International Journal of Business in Society, Vol. 17,No.3, pp.1-37.

6. Alkhatib,k. (2014). The Determinants of Forward-Looking Information Disclosure. Procedia - Social and Behavioral Sciences, Vol.109, pp.858 - 864 .

7. Allini,A. Rossi,F. Hussainey,K.2016. "The board's role in risk disclosure: an exploratory study of Italian listed state-owned enterprises." Public Money \& Management. Vol.36, No .2 ,pp. 113-120.

8. Alsaeed, K. (2006). The association between firm-specific characteristics and disclosure: The case of Saudi Arabia. Managerial Auditing Journal, Vol. 21, No.5, pp.476-496.

9. Al-Shammari, B. 2014. An Investigation of the Impact of Corporate Governance Mechanisms on Level of Corporate Risk Disclosure: Evidence from Kuwait. International Journal of Business and Social Research (IJBSR), Vol.4, No. 6, pp.51-70. 10. Alzead,R.

Hussainey,K. (2017). Risk Disclosure Practice in Saudi NonFinancial Listed Companies. Corporate Ownership and Control journal, Vol.14, N0. 4, pp. 262-275.

11. Banghøj, J. and Plenborg, T. (2008), "Value relevance of voluntary disclosure in the annual report", Accounting and Finance, Vol. 48, pp. 159-180.

مجلة الدراسات التجارية المعاصرة


12. Barako, G., P. Hancock. and Y. Izan. 2006. Factors influencing voluntary corporate disclosure by Kenyan companies. Corporate Governance: An International Review, Vol.14 , No.2, pp.107125 .

13. Bassett, M., Koh, P.S. and Tutticci, I. (2007), "The association between employee stock option disclosures and corporate governance: evidence from an enhanced disclosure regime", British Accounting Review, Vol. 39 No. 4, pp. 303-322.

14. Beasley, M. S., Clune, R., and Hermansion, D.R. (2005). Enterprise risk management: an empirical analysis of factors associated with the extent of implementation. Journal of Accounting and Public policy, Vol. 24, No.6 ,pp. 512-531.

15. Beretta . S, and Bozzolan. S , 2004. "A framework for the analysis of firm risk communication", The International Journal of Accounting, Vol. 39, No.3,pp. 88-265.

16. Cabedo .J. D , and Tirado . J.M, 2004."The disclosure of risk in financial statements", Accounting Forum, Vol. 28,No.2, pp. 181-200.

17. Carcello, J. V., \& Neal, T. L. (2000). Audit committee composition and auditor reporting. The Accounting Review, Vol.75,No.4, pp.453-467.

18. Carmona,P. Fuentes,C. Ruiz,C.2016. Risk disclosure analysis in the corporate governance annual report using Fuzzy- set qualitative comparative analysis . Available at http://www.scielo.br/scielo.php?script=sci_arttext\&pid=S003475902016000300342 accessed at 10 March 2017.

19. Coyle, B., (2002), "Risk Awareness and Corporate Governance", Financial World Publishing: UK. Book. Available at : https://books.google.com.eg/books? id=iPtxXEMwzWkC\&printsec $=$ frontcover $\& d q=\% 22$ Risk + Awareness + and + Corporate + Govern ance\%22, + Financial + World + Publishing: $+U K . \& h l=a r \& s a=X \& v$ ed=0ahUKEwj_iofijoPUAhXBWRQKHRSECYAQ6AEIKjAB\#v=o nepage \& $\& \&=$ false. Accessed at 10 March 2017.

20. Deumes, R. , 2008 . "Corporate risk reporting a content analysis of narrative risk disclosures in prospectuses", Journal of Business Communication, Vol. 45, No. 2, pp. 120-57.

21. Deumes, R., \& Knechel, W. (2008). Economic incentives for voluntary reporting on internal risk management and control systems. Auditing: A Journal of Practice \& Theory. Vol.27, No.1, pp. 35-66.

22. Dobler, M. (2008), "Incentives for risk reporting: a discretionary disclosure and cheap talk approach", The International Journal of Accounting, Vol. 43 No. 1, pp. 184-206.

مجلة اللراسات التجارية الععاصرة


23. Domínguez,L.R. Gámez,L.C.N.(2014). Corporate reporting on risks: Evidence from Spanish companies. Spanish Accounting Review Vol.17,No. 2, pp.116-129

24. Donnelly, R. Mulcahy M. (2008) 'Board Structure, Ownership and Voluntary Disclosure in Ireland' Corporate Governance: $\boldsymbol{A n}$ International Review, Vol. 16, No.5, pp. 416-429.

25. EGX. (2016). Annual Report. Cairo: The Egyptian Exchange. http://www.egx.com.eg/English/Services_Reports.aspx

26. Egyptian Institute of Directors. (2016). Guide to Corporate Governance. Cairo: Egyptian Institute of Directors (in Arabic).

27. Elfeky,M.2017. The extent of voluntary disclosure and its determinants in emerging markets: Evidence from Egypt. The Journal of Finance and Data Science, Vol. 3 , pp.45-59.

28. Elgammal,M. Hussainey, K. Ahmed,F.(2018). Corporate Governance and Voluntary Risk and Forward-looking Disclosures. Journal of Applied Accounting Research .

29. Elshandidy, T. and Neri, L. (2015), "Corporate governance, risk disclosure practices, and market liquidity: comparative evidence from the UK and Italy", Corporate Governance: An International Review Forthcoming. Vol. 23,No.4,pp. 331-356

30. Elshandidy, T., I. Fraser, and K. Hussainey. 2013. "Aggregated, Voluntary, and Mandatory Risk Disclosure Incentives: Evidence from UK FTSE All-share Companies." International Review of Financial Analysis, Vol.30,pp. 320-333.

31. Elzahar,H. Hussainey,K. (2012). Determinants of narrative risk disclosures in UK interim reports. The Journal of Risk Finance, Vol. 13 No. 2 pp. 133 - 147.

32. Ezat , A.N 2014. Risk Disclosure for EGX 100 Egyptian Listed Companies: Trends, Determinants and Consequences. Available at https://www.researchgate.net/publication/283855818

33. Fukukawa,H.Kim,H.2017. Effects of audit partners on clients' business risk disclosure. Available at : http://www.tandfonline.com/doi/abs/10.1080/00014788.2017.129 9619?journalCode $=$ rabr20 Accessed at 16 September 2017

34. Habbash,M Awad,E.A. Hussainey,K.(2016 ) . Corporate Governance and Risk Disclosure: Evidence from Saudi Arabia. Managerial Auditing Journa,. Vol.13, No.2 pp.1-17

35. Hassan , N,S,M. 2013 Measuring the impact of the quality standards of corporate risk disclosure and its impact on the cost of capital: an empirical study in the Egyptian environment " PHD thesis in Arabic, Faculty of Commerce, University of Cairo

مجلة الداسات التجارية المعاصرةة


36. Hassan, M. K. (2009). UAE corporations-specific characteristics and level of risk disclosure. Managerial Auditing Journal, Vol.24, No.7,pp. 668-687.

37. Ibrahim,A. Habbash,M. Hussainey,K.(2018). Corporate Governance and Risk Disclosure:Evidence from Saudi Arabia. International Journal of Accounting, Auditing and Performance Evaluation.

38. Institute of Chartered Accountants in England and Wales. (1997). Financial Reporting of Risk: Proposals for a Statement of Business Risk. London: ICAEW.

39. International Accounting Standard Board. 2008 . International Accounting Standard ( IFRS : 7 ) Financial instruments : disclosures . London : IASB

40. Kakanda, M.M., B. Salim and S. Chandren, 2016. Review of the relationship between board attributes and firm performance. Asian Journal of Finance \& Accounting, Vol.8,No.1,pp. 168-181.

41. Kakanda, M.M., B. Salim and S. Chandren, 2017. Corporate governance, risk management disclosure, and firm performance: a theoretical and empirical review perspective. Asian Journal of Finance \& Accounting, Vol.7,No.1, pp. 836-845 .

42. Konishi, N., \& Ali, M. (2007). Risk reporting of Japanese companies and its association with corporate characteristics. International Journal of Accounting Auditing and Performance Evaluation, Vol.4, No.3,pp. 263-285.

43. Kurniawanto,H . Suhardjanto,D. Bandi. Agustiningsih,S.W. 2017. Corporate Governance and Corporate Risk Disclosure: Empirical Evidence of Non-Financial Companies Listed in Indonesia Stock Exchange. Review of Integrative Business and Economics Research, Vol. 6, No.4,pp.225-270.

44. Lajili, K., \& Zeghal, D. (2005). A content analysis of risk management disclosures in Canadian annual reports. Canadian Journal of Administrative Sciences, Vol. 11, No. 2, pp. 125-42.

45. Lajili,K.( 2009). Corporate Risk Disclosure and Corporate Governance. Journal of Risk Financial Management , Vol.2,No.1,pp. 94- 117.

46. Lim,S. Matolcsy,Z. Chow,D.2007 . The Association between Board Composition and Different Types of Voluntary Disclosure. European Accounting Review.

47. Linsley, P. and Shrives, P. (2005). Examining risk reporting in UK public companies. Journal of Risk Finance, Vol.6,No.4, pp. 292 305.

مجلة الاراسات التجارية المعاصرةة


48. Linsley, P. M., \& Shrives, P. J. (2006). Risk reporting: A study of risk disclosures in the annual reports of UK companies. The British Accounting Review, Vol.38,No.4, pp.387-404.

49. Linsley, P., Shrives, P., Crumpton, M. (2006). Risk disclosure: an exploratory study of UK and Canadian banks. Journal of Banking Regulation, Vol.7,No. (3/4), pp. 268-282.

50. Madawaki, A. and N. A. Amran. 2013. Audit committees: How they affect financial reporting in Nigerian companies. Journal of Modern Accounting and Auditing. Vol.9, No. 8, pp.1070-1080.

51. Mallin, C. (2002). The relationship between corporate governance, transparency and financial disclosure. Corporate Governance: $\boldsymbol{A n}$ International Review, Vol.10, No.4,pp. 253-255.

52. Marn, J. T. K., \& Romuald .D.F. (2012). The Impact of Corporate Governance Mechanism and Corporate performance: A study of Listed Companies in Malaysia. Journal for the Advancement of Science \& Arts, Vol.3, No.1,pp. 31-45.

53. Mensah,B.2015. The Determinants of Financial Ratio Disclosures and Quality: Evidence from an Emerging market. International Journal of Accounting and Financial Reporting. Vol. 5, No. 1,pp.188-211.

54. Mokhtar,E. Mellett,H. (2013) "Competition, corporate governance, ownership structure and risk reporting", Managerial Auditing Journal, Vol. 28 Issue: 9, pp.838-865.

55. Mousa,G. Elamir,EL.2013 . Content Analysis of Corporate Risk Disclosures: The Case of Bahraini Capital Market. Global Review of Accounting and Finance. Vol. 4. No. 1. March 2013. pp. 27 - 54.

56. Neri, L. (2010). The informative capacity of risk disclosure: evidence form Italian stock market. Proceedings of the Fifth international workshop on accounting and regulation conference. European Institute for Advanced Studies in Management. Retrieved on 26th February 2011 from SSRN website: http://papers.ssrn.com/sol3/papers.cfm?abstract_id=1651504 Accessed 10 August 2016.

57. Ntim,C. Lindop,S. Thomas,D. (2013). Corporate governance and risk reporting in South Africa: A study of corporate risk disclosures in the pre- and post-2007/2008 global financial crisis periods. International Review of Financial Analysis. Vol.30,pp.363-383.

58. Oliveira, J., Rodrigues, L. L. \& Craig, R. (2011). Risk related disclosure by Non-finance Companies: Por $\neg$ tuguese practices and disclosure characteristics. Managerial Auditing Journal, Vol.26, No.9, pp. 817-839 .

مجلة الاراسات التجارية الععاصرة"


59. Saggar,R. Singh,B. 2017. "Corporate governance and risk reporting: Indian evidence", Managerial Auditing Journal, Vol. 32 Issue: 4/5, pp.378-405.

60. Singh, M., Mathur, I. and Gleason, K. (2004), "Governance and performance implications of diversification strategies: evidence from large US firms', Financial Review, Vol. 39, pp. 489-526.

61. Soliman, M. M., and A. A. Ragab. 2014. Audit committee effectiveness, audit quality and earnings management: an empirical study of the listed companies in Egypt. Research Journal of Finance and Accounting . Vol.5,No.2, pp. 155-166.

62. Solomon, J., Solomon, A., Norton, S. (2000). A conceptual framework for corporate risk disclosure emerging from the agenda for corporate governance reform. British Accounting Review, Vol.32,No.4,pp. 447-478.

63. Souabni, S. (2011). Predicting an uncertain future: narrative reporting and risk information. The Association of Chartered Certified Accountants. London. Available at : https://www.google.com.eg/url? sa $=t \& r c t=j \& q=\&$ esrc $=s \&$ source $=$ web\& $c d=1 \& c a d=r j a \&$ uact $=8 \&$ ved $=0 a h U K E w i F n d q e l s H W A h W$ FuxQKHYG9BOIQFgguMAA\&url=http\%3A\%2F\%2Fwww.acc aglobal.com\%2Fcontent\%2Fdam\%2Facca\%2Fglobal\%2FPDFtechnical\%2Ffinancial-reporting\%2Fpol-afpuf.pdf\&usg=AFQjCNG9ZJ0L_eu9_9rRyXdbVLaurounNw accessed 4 August 2016.

64. Uyar,A. Kilic,M.2012. Influence of corporate attributes on forward-looking information disclosure in publicly traded Turkish corporations. Procedia - Social and Behavioral Sciences .Vol.62, pp. $244-252$.

65. Vandemele, S. Vergauwen ,P. Michiels,A. 2009. Management Risk Reporting Practice and their Determinants: A study of Belgian listed firms. Available at http://www.doclib.uhasselt.be/dspace/bitstream/1942/9392/2/corp orateriskB.pdf Accessed 5 June 2016

66. Xie, B., W. N. Davidson. and P. J. DaDalt. 2003. Earnings management and corporate governance: the role of the board and the audit committee. Journal of Corporate Finance Vol.9, No. 3,pp. 295-316.

67. Zhang,X. Taylor,D. Qu ,W. Oliver,J. 2013 . corporate risk disclosures : influence of institutional shareholders and audit committee . Corporate Ownership \& Control. Vol. 10, Issue 4, pp.341-354. 
Appendix 1

A list of the sample companies

\begin{tabular}{|c|c|}
\hline Industry sectors & Sampled companies \\
\hline Real Estate &  \\
\hline Chemicals & $\begin{array}{l}\text { 1- } \text { Sidi Kerir Petrochemicals } \\
\text { 2- Kafr El Zayat Pesticides }\end{array}$ \\
\hline Construction and Materials & 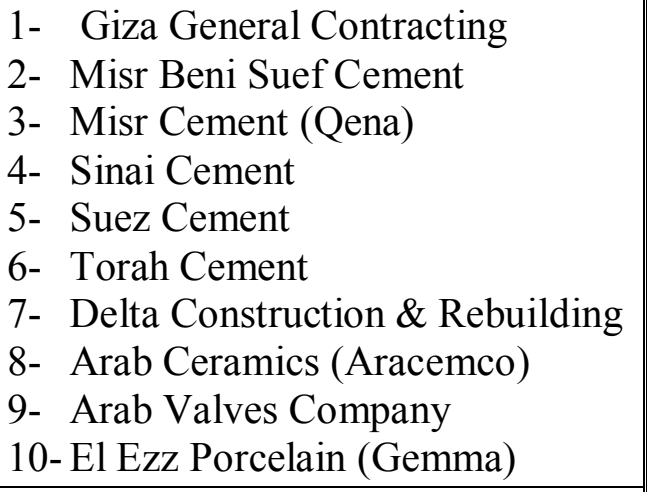 \\
\hline Food and Beverage & $\begin{array}{ll}\text { 1- } & \text { Cairo Poultry } \\
\text { 2- } & \text { Extracted Oils } \\
\text { 3- } & \text { Ismailia Misr Poultry } \\
\text { 4- } & \text { AJWA for Food Industries } \\
& \text { company Egypt } \\
\text { 5- } & \text { Juhayna Food Industries } \\
\end{array}$ \\
\hline
\end{tabular}




\begin{tabular}{|c|c|}
\hline $\begin{array}{l}\text { Healthcare and } \\
\text { Pharmaceuticals }\end{array}$ & $\begin{array}{l}\text { 1- Alexandria New Medical Center } \\
\text { 2- Sabaa International Company for } \\
\text { Pharmaceutical and Chemical }\end{array}$ \\
\hline $\begin{array}{l}\text { Industrial goods, service } \\
\text { and automobile }\end{array}$ & $\begin{array}{ll}\text { 1- } & \text { Electro Cable Egypt } \\
\text { 2- } & \text { El Arabia Engineering Industries } \\
\text { 3- El Nasr Transformers (E1 Maco) } \\
\text { 4- Egyptian Transport } \\
\text { (EGYTRANS) } \\
\text { 5- GB AUTO } \\
\text { 6- Delta For Printing \& Packaging } \\
\text { 7- Universal For Paper and } \\
\text { Packaging Materials }\end{array}$ \\
\hline Oil and gas & $\begin{array}{lll}\text { GMC Group } & \text { for } & \text { Industrial } \\
\text { Commercial } & \& & \text { Financial } \\
\text { Investments } & & \\
\end{array}$ \\
\hline $\begin{array}{l}\text { Personal and Household } \\
\text { products }\end{array}$ & $\begin{array}{l}\text { 1- Oriental Weavers } \\
\text { 2- Dice Sport \& Casual Wear }\end{array}$ \\
\hline Basic resources & $\begin{array}{l}\text { 1- EL Ezz Aldekhela Steel } \\
\text { Alexandria } \\
\text { 2- Arab Aluminum }\end{array}$ \\
\hline Retail & Assiut Islamic Trading \\
\hline Media & Egyptian Media Production City \\
\hline Technology & $\begin{array}{l}\text { Raya Holding For Technology } \\
\text { And Communications }\end{array}$ \\
\hline Telecommunication & $\begin{array}{l}\text { 1- } \text { Orange } \\
\text { 2- } \text { Telecom Egypt }\end{array}$ \\
\hline Travel and Leisure & $\begin{array}{l}\text { 1- Remco for Touristic Villages } \\
\text { Construction } \\
\text { 2- Egyptian for Tourism Resorts } \\
\text { 3- Pyramisa Hotels } \\
\text { 4- Trans Oceans Tours } \\
\text { 5- Golden Coast Company } \\
\text { 6- Sharm Dreams Company for } \\
\text { Tourism Investment }\end{array}$ \\
\hline Utilities & $\begin{array}{l}\text { Natural Gas \& Mining Project } \\
\text { (Egypt Gas) }\end{array}$ \\
\hline
\end{tabular}




\section{Appendix 2}

\section{Decision rules for voluntary risk disclosures}

1- To identify risk disclosures a broad definition of risk is to be adopted as explained below.

2- Sentences are to be coded as risk disclosures if the reader is informed of any opportunity or prospect, or of any hazard, danger, harm, threat or exposure, that has already impacted upon the company or may impact upon the company in the future or of the management of any such opportunity, prospect, hazard, harm, threat or exposure.

3- The risk definition just stated shall be interpreted such that 'good' and 'bad' 'risks' and 'uncertainties' will be deemed to be contained within the definition.

4- Although the definition of risk is broad, disclosures must be specifically stated; they cannot be implied.

5- The risk disclosures shall be classified according to the grid in Appendix 3 "risk categories".

6- If a sentence has more than one possible classification, the information will be classified into the category that is most emphasized within the sentence.

7- Any disclosure that is repeated shall be recorded as a risk disclosure sentence each time it is discussed.

8- If a disclosure is too vague in its reference to risk, then it shall not be recorded as a risk disclosure.

\section{Appendix 3}

Voluntary risk disclosure categories

\begin{tabular}{|c|c|}
\hline Financial risk & $\begin{array}{l}\text { 1- } \begin{array}{l}\text { Historical summary of financial } \\
\text { data for the last years }\end{array} \\
\text { 2- } \text { Review of current financial } \\
\text { results } \\
\text { 3- } \text { Impairment of assets value } \\
\text { 4- } \text { Inflation of assets value } \\
\text { 5- } \text { Contingent Liabilities } \\
\text { 6- } \\
\text { Financing for the company's } \\
\text { projects ( equity / liability ) }\end{array}$ \\
\hline Operational risk & $\begin{array}{l}\text { 1- Customers' relations and } \\
\text { satisfaction risk } \\
\text { 2- Loss of major customers risk } \\
\text { 3- } \text { Risk of Product or service } \\
\text { development and failure ( reject } \\
\text { product, sales ) }\end{array}$ \\
\hline
\end{tabular}




\begin{tabular}{|c|c|}
\hline & $\begin{array}{l}\text { 4- Uncommon business fluctuations } \\
\text { in demand } \\
\text { 5- Sourcing risk. (Insufficient } \\
\text { resources and raw material) }\end{array}$ \\
\hline Empowerment risk & $\begin{array}{l}\text { 1- Leadership and management risk } \\
\text { 2- } \text { Outsourcing risk } \\
\text { 3- Employee training }\end{array}$ \\
\hline $\begin{array}{l}\text { Information processing } \\
\text { and technology risk }\end{array}$ & $\begin{array}{ll}\text { 1- } & \text { Risk of technical and system } \\
& \text { failure (access and availability) } \\
\text { 2- } & \text { Risk of rapid development in } \\
\text { technology (infrastructure) }\end{array}$ \\
\hline Integrity risk & 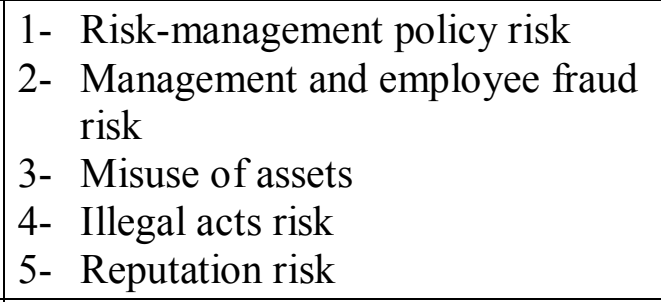 \\
\hline Strategic risk & 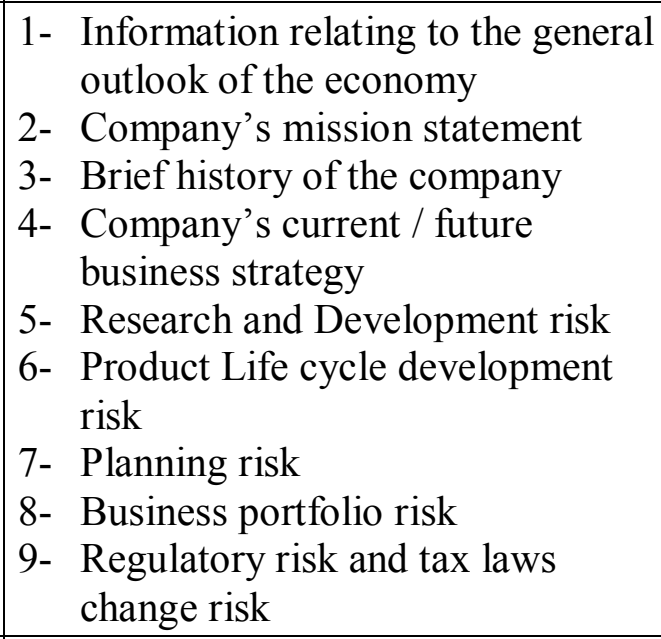 \\
\hline Legal risk & $\begin{array}{l}\text { Claim against the firm (failure to } \\
\text { meet the terms of a contract or non- } \\
\text { compliance with laws and } \\
\text { regulations). }\end{array}$ \\
\hline
\end{tabular}

